\title{
Preparation of Monodisperse Porous Silica Particles Using Poly(Glycidyl Methacrylate) Microspheres as a Template
}

\author{
S. GRAMA ${ }^{1}$, D. HORÁK ${ }^{1}$ \\ ${ }^{1}$ Institute of Macromolecular Chemistry, Academy of Sciences of the Czech Republic, Prague, \\ Czech Republic
}

Received June 10, 2015

Accepted July 16, 2015

\begin{abstract}
Summary
Monodisperse macroporous poly(glycidyl methacrylate) (PGMA) microspheres were used as a template for preparing porous silica particles. The starting polymer microspheres that were $9.3 \mu \mathrm{m}$ in size were synthesized by multistep swelling polymerization using a modified Ugelstad technique. Subsequently, silica $\left(\mathrm{SiO}_{2}\right)$ was deposited on the surface and inside the PGMA microspheres to produce poly(glycidyl methacrylate)-silica hybrid particles (PGMA$\mathrm{SiO}_{2}$ ). Upon calcination of the PGMA-SiO ${ }_{2}$ microspheres, porous silica particles were formed. The morphology, particle size, polydispersity and inner structure of the silica microspheres were investigated by scanning and transmission electron microscopy. Thermogravimetric analysis and dynamic adsorption of nitrogen determined the amount of silica formed and its specific surface area. Compared with the starting PGMA microspheres, the size of the porous silica particles decreased by up to $30 \%$. These porous silica microspheres are promising for chromatography and biomedical applications.
\end{abstract}

\section{Key words \\ Microspheres • Monodisperse • Silica • Poly(glycidyl methacrylate) • Porous}

\section{Corresponding author}

S. Grama, Institute of Macromolecular Chemistry, Academy of Science of the Czech Republic, Heyrovskeho Sq. 2, 16206 Prague 6, Czech Republic. E-mail: grama@imc.cas.cz

\section{Introduction}

For decades, porous particles, especially those that are spherical in shape, have been of great research interest due to their applicability for separating molecules
(Li et al. 2013), catalysis (Lu and To 2009, Bogdan et al. 2007), diagnostics (Sinitsyna et al. 2012), sensors (Salinas-Castillo et al. 2010) and drug delivery systems (Elbert 2011). Depending on the pore size, the particles are classified as macro-, meso- and microporous, for pores $>50 \mathrm{~nm}$, within the range of $2-50 \mathrm{~nm}$ and $<2 \mathrm{~nm}$ respectively. Moreover, size, particle size distribution, chemical structure and functionality are important features when selecting particles for a required application. For example, functional nanosized particles are often used in medicine ( $\mathrm{Li}$ et al. 2010), while chromatography (Haginaka 2008) requires monodisperse microspheres with a size in the micrometer range adjusted according to the separation purposes.

Many techniques can be employed when preparing polymer microspheres. Suspension, dispersion, precipitation, multistep, emulsion and microfluidic polymerizations are the main methods used to form porous polymer particles. In all cases, the application should be kept in mind prior to choosing the process of production (Gokmen and Du Prez 2012). In addition, the use of different porogens during polymerization leads to the formation of porous beads with the desired pore size and distribution (Dubinsky et al. 2009).

Silica particles are typically synthesized using a sol-gel process from alkylorthosilanes. The method was introduced by Stöber and Fink (Stöber et al. 1968). The method is primarily used for the preparation of nonporous nanosized silica. In order to produce porous silica beads, an alkylamine porogen is often used in combination with the sol-gel process. Even though literature is full of studies about silica particle preparation (Kota et al. 2013, Alothman 2012), it is still quite challenging to synthesize 
monodisperse porous silica microspheres in the size range of 3-0 $\mu \mathrm{m}$. Template techniques are being widely used to control the size and morphology of silica particles. Porous silica can be formed by using different organic templates, such as surfactants (Velikova et al. 2013), polymers (Tsiourvas et al. 2013) and pre-formed molecules (Shen et al. 2015). Monodisperse porous silica microspheres were synthesized using polystyrene crosslinked with divinyl benzene as a template (Meyer et al. 2002). Optionally, mesoporous silica spheres were obtained in the presence of highly interconnected macroporous polyacrylamide (Ahmed et al. 2010).

Silica is biocompatible, optically transparent and relatively environmentally inert. Last but not least, silica is chemically reactive and amenable to the introduction of various functional groups required by biological applications (Knopp et al. 2009). Another advantage of porous silica particles is that iron oxide can be prospectively precipitated inside the pores to provide magnetic properties. The easy functionalization and magnetic properties of microparticles can be then exploited in the separation of cells or proteins and for diagnostics. Recently, we have used functional magnetic porous microspheres to capture cancer cells (Horák et al. 2013, Kuan et al. 2014), biomarkers for detecting Alzheimer's disease (Horák et al. 2014, de la EscosuraMuñiz et al. 2015) and as affinity sorbents (Horák et al. 2012, Kučerová et al. 2014).

With the attempt to design new systems that can be used for the above-mentioned purposes, this paper reports on the preparation of monodisperse porous silica particles by using poly(glycidyl methacrylate) microspheres as a template. The morphology, particle size, polydispersity and inner structure of the silica microspheres were investigated by scanning and transmission electron microscopy. The porous properties were determined by measuring the specific surface area of the silica particles.

\section{Methods}

\section{Preparation of porous silica microspheres}

Tetramethyl orthosilicate (TMOS) and trimethoxy(methyl) silane (TMMS) were supplied by Sigma-Aldrich (St. Louis, USA). Starting PGMA microspheres were synthesized by a multistep swelling polymerization that was first reported by Ugelstad (Ugelstad et al. 1988) with some modifications (Grama et al. 2014b). The silica was formed on the surface and in the inner pores of the starting PGMA microspheres by a three-step procedure based on the Stöber technique (Stöber et al. 1968). The polymer-silica hybrid particles were obtained by filling the PGMA pores with a hydrolysate preformed from TMOS or TMMS under mild conditions, that is, in highly dilute $\mathrm{HCl}$ at $60^{\circ} \mathrm{C}$. It is necessary to mention that no porogens or surfactants were used during the silica formation. The synthesis of monodisperse macroporous poly(glycidyl methacrylate) (PGMA) and poly(glycidyl methacrylate)-silica (PGMA-SiO $\left.{ }_{2}\right)$ microspheres was described elsewhere (Grama et al. 2014b) and (Grama et al. 2014a). The dried PGMA$\mathrm{SiO}_{2}$ microspheres were calcinated at $650{ }^{\circ} \mathrm{C}$ for $6 \mathrm{~h}$ at a heating rate of $10{ }^{\circ} \mathrm{C} / \mathrm{min}$ under air. After calcination, the remaining product consisted of porous silica microspheres that were free from the PGMA polymer microspheres.

\section{Characterization of microspheres}

The microspheres were viewed under an Opton III light microscope (Oberkochen, Germany), a 200S Quanta scanning electron microscope (SEM; FEI; Brno, Czech Republic) equipped with an energy dispersive X-ray analysis (EDAX) and a Tecnai Spirit G2 transmission electron microscope (TEM; FEI). The particle size distribution was determined by the Atlas software (Tescan; Brno, Czech Republic) and at least 500 particles were counted in each experiment. The number-average diameter $\left(D_{n}\right)$, weight-average diameter $\left(\mathrm{D}_{\mathrm{w}}\right)$ and polydispersity index (PDI) were calculated as $\mathrm{D}_{\mathrm{n}}=\Sigma \mathrm{D}_{\mathrm{i}} / \mathrm{N}, \mathrm{D}_{\mathrm{w}}=\Sigma \mathrm{D}_{\mathrm{i}}^{4} / \Sigma \mathrm{D}_{\mathrm{i}}{ }^{3}, \mathrm{PDI}=\mathrm{D}_{\mathrm{w}} / \mathrm{D}_{\mathrm{n}}$, where $\mathrm{D}_{\mathrm{i}}$ is the diameter of $i$-th particle and $\mathrm{N}$ is the total number of particles counted. A thermogravimetric analysis (TGA) was performed in air using a Perkin Elmer 7 thermogravimetric analyzer ranging from 30 to $850^{\circ} \mathrm{C}$ at a heating rate of $10^{\circ} \mathrm{C} \mathrm{min}{ }^{-1}$. The specific surface area $\left(\mathrm{S}_{\mathrm{BET}}\right)$ of the microspheres was determined by liquid nitrogen adsorption (77 K) using a Gemini VII 2390 Analyser (Micromeritics; Norcross, GA, USA).

\section{Results}

The obtained PGMA microspheres were $9.3 \mu \mathrm{m}$ in diameter with a low polydispersity index (PDI = 1.004) (Fig. 1a, Table 1) conforming to their monodispersity. An amplified view revealed a rather rough surface of the particles with distinct pores (Fig. 1b). A TEM micrograph from a microsphere cross- 
section showed its inner structure consisting of large pores (Fig. 1c). The porous structure of PGMA microspheres was confirmed by measurements showing the specific surface area to reach $85.6 \mathrm{~m}^{2} / \mathrm{g}$ (Table 1).

Table 1. Properties of microspheres.

\begin{tabular}{|c|c|c|c|c|c|c|}
\hline \multirow[t]{2}{*}{ Microspheres } & \multirow{2}{*}{$\begin{array}{l}\text { Silanization } \\
\text { agent }\end{array}$} & \multirow{2}{*}{$\begin{array}{c}D_{\mathrm{n}}^{\mathrm{a}} \\
(\mu \mathrm{m})\end{array}$} & \multirow[t]{2}{*}{ PDI $^{b}$} & \multicolumn{2}{|c|}{$\mathrm{SiO}_{2}($ wt.\%) } & \multirow{2}{*}{$\begin{array}{l}S_{\text {BET }}{ }^{\mathrm{c}} \\
\left(\mathrm{m}^{2} / \mathrm{g}\right)\end{array}$} \\
\hline & & & & EDAX $^{d}$ & EDAX $^{\mathrm{e}}$ & \\
\hline$P G M A$ & - & 9.3 & 1.004 & - & - & 85.6 \\
\hline $\mathrm{PGMA}_{\mathrm{SiO}}$ & TMOS & 8.6 & 1.004 & 35.8 & 13.7 & 4.5 \\
\hline $\mathrm{SiO}_{2}$ & TMOS & 7.9 & 1.005 & 19.1 & 26.0 & 331.4 \\
\hline $\mathrm{PGMA}-\mathrm{Me}-\mathrm{SiO}_{2}$ & TMMS & 9.7 & 1.005 & 14.4 & 18.4 & 18.2 \\
\hline $\mathrm{Me}-\mathrm{SiO}_{2}$ & TMMS & 6.0 & 1.006 & 18.9 & 26.3 & 323.6 \\
\hline
\end{tabular}

${ }^{\text {a }}$ Number-average diameter, ${ }^{b}$ Polydispersity index, ${ }^{c}$ Specific surface area, ${ }^{\text {d } E n e r g y ~ d i s p e r s i v e ~ X-r a y ~ a n a l y s i s ~ c o u p l e d ~ w i t h ~ S E M, ~}$

${ }^{\mathrm{e}}$ Energy dispersive $\mathrm{X}$-ray analysis coupled with TEM.

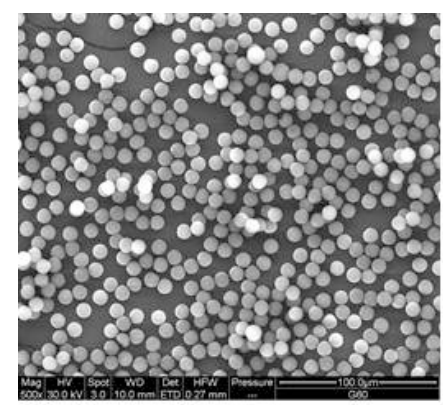

a

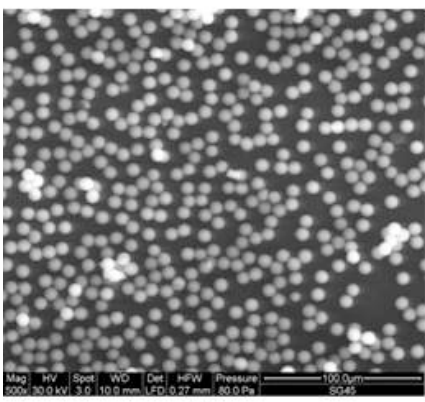

d

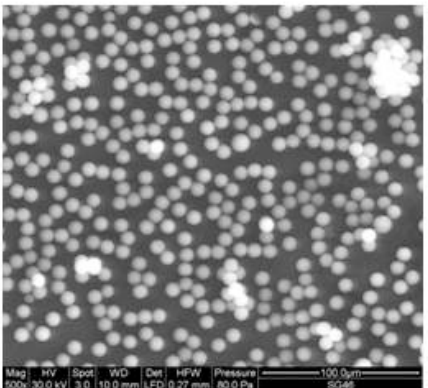

g

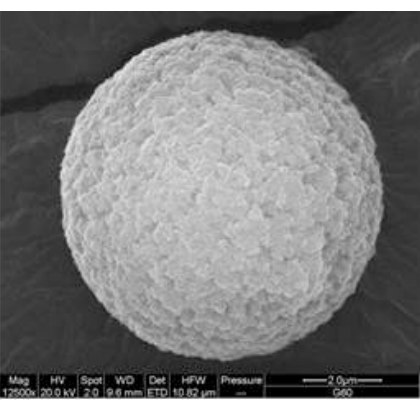

b

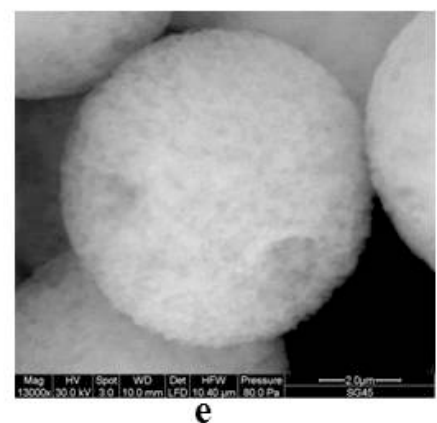

e

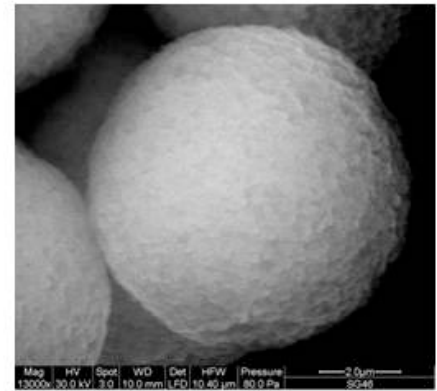

h

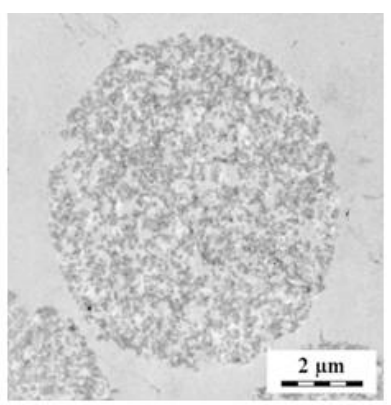

c
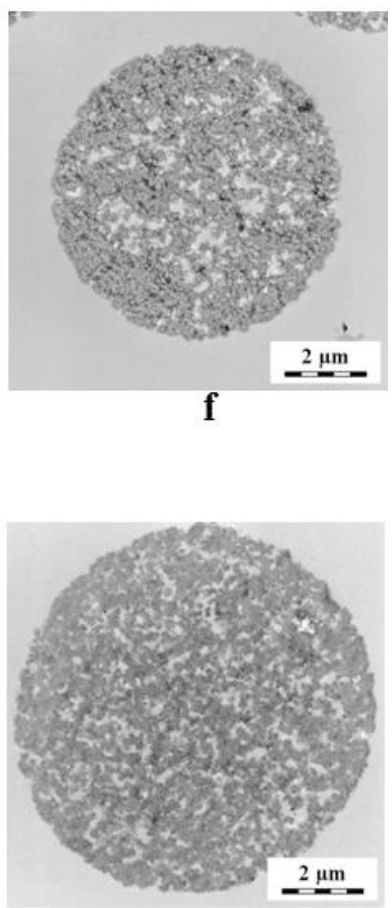

i

Fig. 1. SEM (a, b, d, e, g, h) and TEM micrographs (c, $\mathbf{f}, \mathbf{i})$ of starting PGMA (a-c), PGMA-SiO 2 (d-f) and PGMA-Me-SiO 2 (g-i) microspheres; $(\mathbf{c}, \mathbf{f}, \mathbf{i})$ are particle cross-sections. 


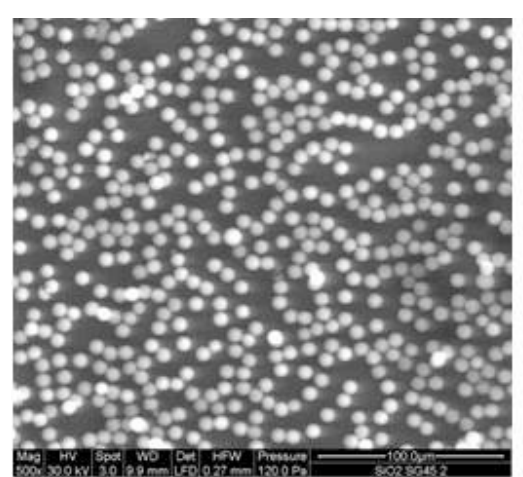

a

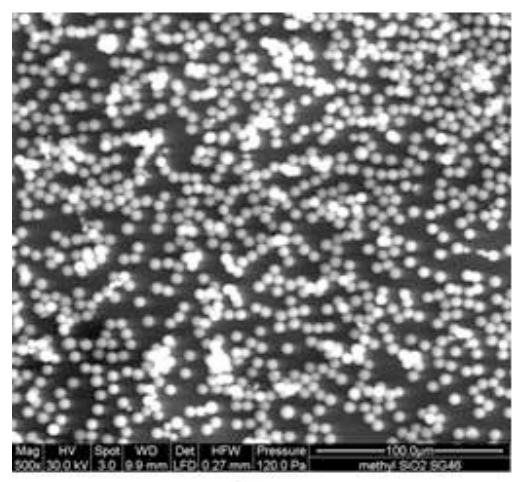

d

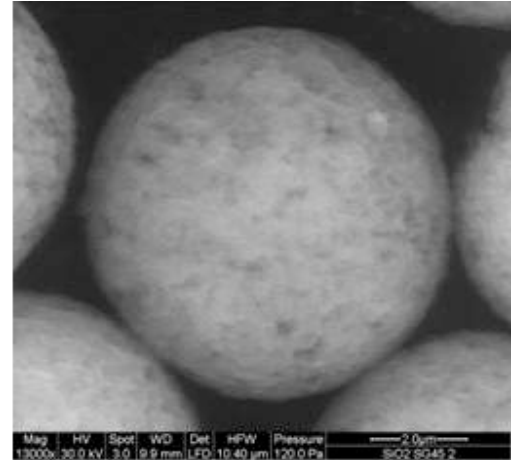

b

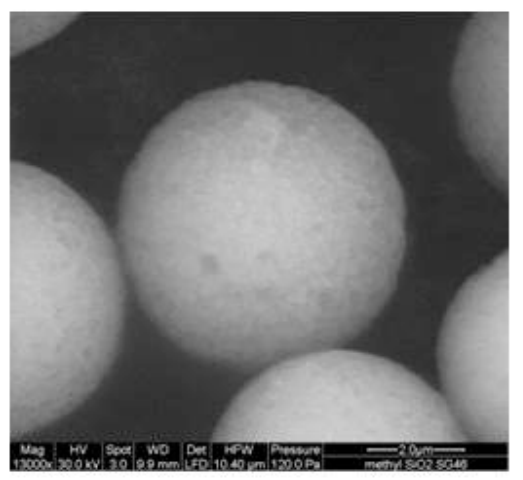

e

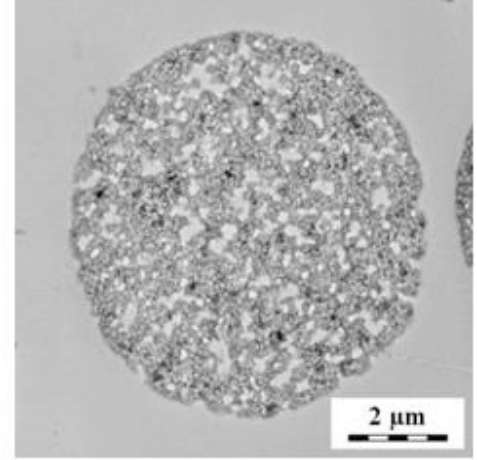

c

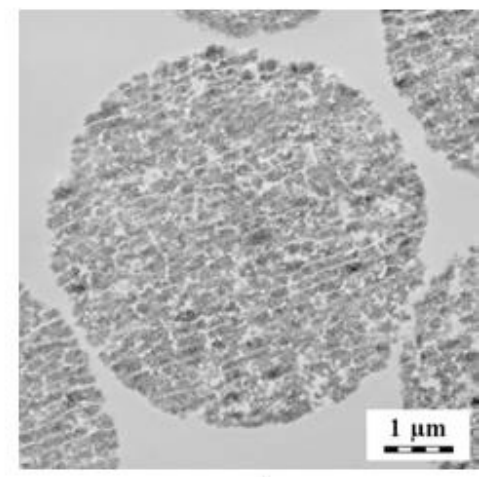

f

Fig. 2. $\mathrm{SEM}(\mathbf{a}, \mathbf{b}, \mathbf{d}, \mathbf{e})$ and $\mathrm{TEM}(\mathbf{c}, \mathbf{f})$ of $\mathrm{SiO}_{2}(\mathbf{a}-\mathbf{c})$ and ${\mathrm{Me}-\mathrm{SiO}_{2}}_{2}$ microspheres; $(\mathbf{c}, \mathbf{f})$ are particle cross-sections.

The resulting $\mathrm{PGMA}-\mathrm{SiO}_{2}$ and poly(glycidyl methacrylate)-methyl-silica (PGMA-Me-SiO ${ }_{2}$ ) microspheres are shown in Figures 1d-f and 1g-i, respectively, documenting that silica was formed both on surface and inside the PGMA pores. The size of the polymer-silica hybrid microspheres was $8.6 \mu \mathrm{m}$ for $\mathrm{PGMA}-\mathrm{SiO}_{2}$ and 9.7 $\mu \mathrm{m}$ for PGMA-Me- $\mathrm{SiO}_{2}$ microspheres, while the monodispersity remained unchanged (Table 1, Figs 1d and 1g). SEM and TEM cross-section micrographs revealed that PGMA pores disappeared by being filled with silica (Figs 1e, 1f, $1 \mathrm{~h}$ and 1i). The pore properties of the hybrid microspheres were investigated by nitrogen adsorption. The specific surface areas were 4.5 and $18.2 \mathrm{~m}^{2} / \mathrm{g}$ for $\mathrm{PGMA}-\mathrm{SiO}_{2}$ and $\mathrm{PGMA}-\mathrm{Me}-\mathrm{SiO}_{2}$ particles, respectively (Table 1).

Upon calcination of PGMA-SiO ${ }_{2}$ and PGMA$\mathrm{Me}-\mathrm{SiO}_{2}$ microspheres, porous $\mathrm{SiO}_{2}$ and $\mathrm{Me}-\mathrm{SiO}_{2}$ particles were obtained. During removal of the polymer template, particles partially shrank, reaching a diameter of $7.9 \mu \mathrm{m}$ for $\mathrm{SiO}_{2}$ and $6.0 \mu \mathrm{m}$ for $\mathrm{Me}^{-\mathrm{SiO}_{2}}$ spheres, while PDI remained unchanged (Table 1, Figs 2a and 2d). While the shrinking of $\mathrm{SiO}_{2}$ particles was not pronounced $(700 \mathrm{~nm})$, the size of the $\mathrm{Me}-\mathrm{SiO}_{2}$ particles was smaller by $30 \%$. The porous character of the particles was confirmed both by electron microscopy and a surface area analysis. After removing the PGMA template, SEM and TEM cross-section micrographs revealed that the $\mathrm{SiO}_{2}$ particles contained rather large and irregular pores, while the $\mathrm{Me}-\mathrm{SiO}_{2}$ microspheres had smaller pores (Figs $2 \mathrm{c}$ and $2 \mathrm{f}$ ). Porous silica formation was additionally confirmed by the relatively high specific surface area, $331.4 \mathrm{~m}^{2} / \mathrm{g}$ for $\mathrm{SiO}_{2}$ and $323.6 \mathrm{~m}^{2} / \mathrm{g}$ for $\mathrm{Me}-\mathrm{SiO}_{2}$ microspheres (Table 1).

SEM and TEM coupled with EDAX provided information about the content of silicon in the PGMA$\mathrm{SiO}_{2}$ and $\mathrm{SiO}_{2}$ microspheres. It amounted to 16.7 (SEM) and 6.4 wt.\% (TEM) in PGMA-SiO ${ }_{2}$, which represented 35.8 and 13.7 wt.\% of $\mathrm{SiO}_{2}$. The content of $\mathrm{Si}$ in $\mathrm{SiO}_{2}$ particles (8.9 and $12.2 \mathrm{wt} . \%$ according to SEM and TEM, respectively) corresponded to 19.1 and $26.0 \mathrm{wt} . \%$ amount of $\mathrm{SiO}_{2}$. In PGMA-Me- $\mathrm{SiO}_{2}$ and $\mathrm{Me}-\mathrm{SiO}_{2}$ particles, the amount of silica increased from 14.4 (SEM) and 18.4 wt. \% (TEM) for PGMA-Me-SiO ${ }_{2}$ to 18.9 and $26.3 \mathrm{wt} . \%$,

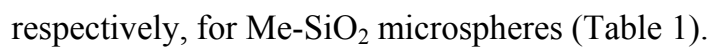

TGA was used to study the silica content in the PGMA- $\mathrm{SiO}_{2}$ microspheres (Fig. 3). At temperatures below $230^{\circ} \mathrm{C}$, a rather small weight loss was found that 
was attributed to the evaporation of solvents. Starting from $250^{\circ} \mathrm{C}$, fast decomposition of organic compounds was observed. Full decomposition occurred at $550{ }^{\circ} \mathrm{C}$; however, a residual amount of $\mathrm{SiO}_{2}$ still persisted at $750{ }^{\circ} \mathrm{C}$. The amount of silica remaining at the end of the PGMA decomposition was 33.4 wt.\% for $\mathrm{SiO}_{2}$ and 40.5 wt. $\%$ for $\mathrm{Me}_{-} \mathrm{SiO}_{2}$.

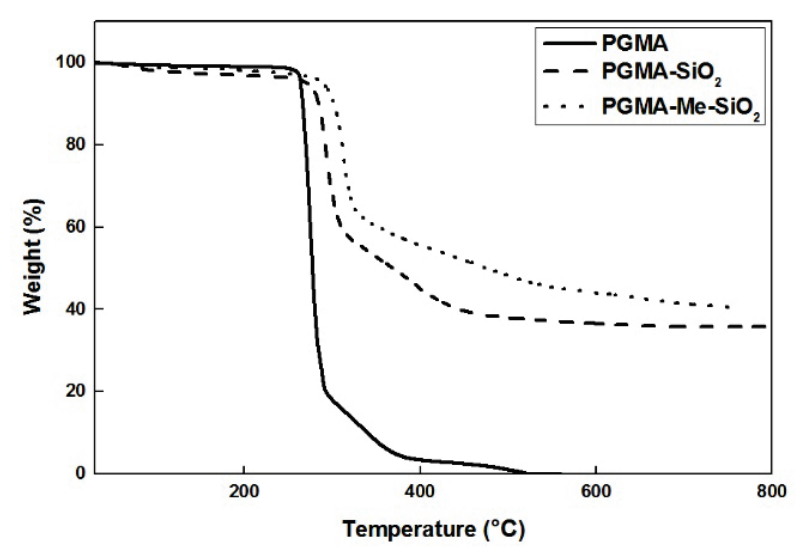

Fig. 3. TGA of PGMA, $P G M A-\mathrm{SiO}_{2}$ and $\mathrm{PGMA}-\mathrm{Me}-\mathrm{SiO}_{2}$ microspheres.

\section{Discussion}

PGMA microspheres are of growing interest as a matrix for producing inorganic particles due to their macroporosity and monodispersity. In this report, $9 \mu \mathrm{m}$ PGMA microspheres were successfully used as templates for developing porous silica particles in the absence of any auxiliary surfactant or porogen. The macroporosity of the PGMA microspheres plays in important role in the formation of porous silica particles.

During the silanization process, when PGMA$\mathrm{SiO}_{2}$ and PGMA-Me-SiO 2 hybrid microspheres are formed, the monodispersity remains unchanged, thereby confirming the absence of silica outside of the PGMA particle surface. It is interesting to note that while the diameter of $\mathrm{PGMA}_{-} \mathrm{SiO}_{2}$ microspheres decreased $\left(D_{\mathrm{n}}=8.6 \mu \mathrm{m}\right)$, the size of PGMA-Me-SiO 2 increased $\left(D_{\mathrm{n}}=9.7 \mu \mathrm{m}\right)$. This can be explained by different mechanisms of condensing silanol into silica. While silica was formed within the microsphere bulk filled with TMOS, the silica from TMMS had a tendency to phaseseparate and coat the particles, thus increasing their size (Grama et al. 2014a). This behavior influenced the final size of the silica particles. The lower specific surface area of PGMA-SiO 2 and PGMA-Me-SiO 2 compared with the starting PGMA microspheres were due to the formation of silica on the microsphere surface, which was in agreement with the SEM micrographs. Incorporating silica in PGMA particles increased their thermal stability. This increase of thermal stability of the hybrid microspheres was documented by a shift of decomposition temperature in PGMA particles to higher values.

After the calcination of the PGMA matrix, porous silica microspheres were obtained. During removal of the polymer template, the particles partially shrank. The difference between the final size of the $\mathrm{SiO}_{2}$ and $\mathrm{Me}-\mathrm{SiO}_{2}$ particles can be attributed to the fact that while TMOS formed silica mostly inside the PGMA pores, TMMS had the tendency to coat the particle surface, as previously mentioned. If monodisperse porous silica microspheres were prepared from tetraethylorthosilane using ethylenediamine-functionalized PGMA microspheres as a template, calcination of the polymer produced silica with a porous or hollow structure maintaining the same size as the initial polymer microspheres (He et al. 2012). In order to avoid the shrinking, tetra- $n$-butylammonium bromide or tetramethylammonium hydroxide were present during silanization. In our approach, TMOS and TMMS were silanization agents used to control the morphology of the silica particles. The $\mathrm{SiO}_{2}$ produced from TMOS had a tendency to fill in the pores of the PGMA microspheres, while $\mathrm{Me}-\mathrm{SiO}_{2}$ mostly formed on surface of the PGMA particles. This is the reason why $\mathrm{SiO}_{2}$ particles, after removal of the polymeric template, maintained the same size as the initial microspheres, while the diameter of the $\mathrm{Me}-\mathrm{SiO}_{2}$ particles dramatically decreased. The pore structure of the silica particles depended on the silanization agent that was used. According to the specific surface area and the TEM of particle cross-sections, larger irregular pores were present in the silica formed from the TMOS silanization agent, in contrast to the small pores of the Me$\mathrm{SiO}_{2}$ microsphere. The $\mathrm{Si}$ signal detected on $\mathrm{SiO}_{2}$ and $\mathrm{Me}-$ $\mathrm{SiO}_{2}$ microspheres by EDAX-coupled SEM and TEM was strong. Only in $\mathrm{SiO}_{2}$ particles did the content of silicon decrease compared with $\mathrm{PGMA}-\mathrm{SiO}_{2}$.

In conclusion, porous silica particles were developed by using monodisperse, macroporous PGMA microspheres as a template. The porous silica particles maintained their monodispersity after removal of the PGMA microspheres, and in fact they even shrank in size by $30 \%$. The selection of the silanization agents influenced the size and porous structure of the final silica microspheres. The amount of formed silica determined 
by electron microscopy coupled with EDAX and a themorgravimetric analysis reached $40 \mathrm{wt} . \%$. The high values of the specific surface area of $\mathrm{SiO}_{2}$ and $\mathrm{Me}-\mathrm{SiO}_{2}$ microparticles suggest the formation of a porous structure. The newly-developed porous silica particles are intended for applications in chromatography, biology and as a catalyst. The potential range of applications of silica microspheres can be further extended either by functionalization and/or precipitation of magnetic iron oxides inside the pores of the microspheres.

\section{Conflict of Interest}

There is no conflict of interest.

\section{Acknowledgements}

This work was supported by the Ministry of Education, Youth and Sports of the Czech Republic (projects EE2.3.30.0029 and Biocev CZ.1.05/1.1.00/02.0109).

\section{References}

AHMED A, CLOWES R, WILLNEFF E, MYERS P, ZHAG H: Porous silica spheres in macroporous structures and on nanofibres. Phil Trans $R$ Soc A 368: 4351-4370, 2010.

ALOTHMAN ZA: A Review: Fundamental aspects of silicate mesoporous materials. Materials 5: 2874-2902, 2012.

BOGDAN AR, MASON BP, SYLVESTER KT, MCQUADE DT: Improving solid supported catalyst productivity by using simplified packed-bed microreactors. Angew Chem Int Ed 46: 1968-1701, 2007.

DUBINSKY S, PARK JI, GOUREVICH I, CHAN C, DEETZ M, KUMACHEVA E: Toward controlling the surface morphology of macroporous copolymer particles. Macromolecules 42: 1990-1994, 2009.

ELBERT DL: Liquid-liquid two-phase systems for the production of porous hydrogels and hydrogel microspheres for biomedical applications: A tutorial review. Acta Biomater 7: 31-56, 2011.

DE LA ESCOSURA-MUÑIZ A, PLICHTA Z, HORÁK D, MERKOÇI A: Alzheimer's disease biomarkers detection in human samples by efficient capturing through porous magnetic microspheres and labelling with electrocatalytic gold nanoparticles. Biosens Bioelectron 67: 162-169, 2015.

GOKMEN MT, DU PREZ FE: Porous polymer particle-A comprehensive guide to synthesis, characterization, functionalization and applications. Prog Polym Sci 37: 365-405, 2012.

GRAMA S, BOIKO N, ROSTYSLAV B, KLYUCHIVSKA O, ANTONYUK V, STOIKA R, HORAK D: Novel fluorescent poly(glycidyl methacrylate)-silica microspheres. Eur Polym J 56: 92-104, 2014a.

GRAMA S, PLICHTA Z, TRCHOVÁ M, KOVÁŘOVÁ J, BENEŠ MJ, HORÁK D: Monodisperse macroporous poly(glycidyl methacrylate) microspheres coated with silica: design, preparation and characterization. React Funct Polym 77: 11-17, 2014b.

HAGINAKA J: Monodispersed, molecularly imprinted polymers as affinity-based chromatography media. J Chromatogr B 866: 3-13, 2008.

HE J, YANG C, XIONG X, JIANG B: Preparation and characterization of monodisperse porous silica microspheres with controllable morphology and structure. J Polym Sci Part A: Polym Chem 50: 2889-2897, 2012.

HORÁK D, KUČEROVÁ J, KORECKÁ L, JANKOVIČOVÁ B, PALARČÍK J, MIKULÁŠEK P, BÍLKOVÁ Z: New monodisperse magnetic polymer microspheres biofunctionalized for enzyme catalysis and bioaffinity separations. Macromol Biosci 12: 647-655, 2012.

HORÁK D, SVOBODOVÁ Z, AUTEBERT J, COUDERT B, PLICHTA Z, KRÁLOVEC K, BÍLKOVÁ Z, VIOVY J-L: Albumin-coated monodisperse magnetic poly(glycidyl methacrylate) microspheres with immobilized antibodies: Application to the capture of epithelial cancer cells. J Biomed Mater Res Part A 101: 23-32, 2013.

HORÁK D, HLÍDKOVÁ H, HIRAOUI M, TAVERNA M, PROKS V, MÁZL CHÁNOVÁ E, SMADJA C, KUČEROVÁ Z: Monodisperse carboxyl-functionalized poly(ethylene glycol)-coated magnetic poly(glycidyl methacrylate) microspheres: Application to the immunocapture of $\beta$-amyloid peptides. Macromol Biosci 14: 1590-1599, 2014.

KNOOP D, TANG D, NIESSNER R: Bioanalytical applications of biomolecule-functionalized nanometer-sized doped silica particles. Anal Chim Acta 647: 14-30, 2009.

KOTA S, NAOKI S, MAKOT O: Mesoporous silica spherical particles. J Nanosci Nanotechnol 13: 2483-2494, 2013. 
KUAN WC, HORÁK D, PLICHTA Z, LEE WC: Immunocapture of CD133-positive cells from human cancer cell lines by using monodisperse magnetic poly(glycidyl methacrylate) microspheres containing amino groups. Mater Sci Eng C 34: 193-200, 2014.

KUCEROVA J, SVOBODOVA Z, KNOTEK P, PALARCIK J, VLCEK M, KINCL M, HORAK D, AUTEBERT J, VIOVY J-L, BILKOVA Z: PEGylation of magnetic poly(glycidyl methacrylate) microparticles for microfluidic bioassays. Mater Sci Eng C 40: 308-315, 2014.

LI B, ZHOU X, ZHAO Y, SUN L, LI S: Biofunctionalization of silica microspheres for protein separation. Mater Sci Eng C 33: 2595-2600, 2013.

LI S, NGUYEN L, XIONG H, WANG M, HU TC-C, SHE JX, SERKIZ SM, WICKS GG, DYNAN WS: Porous-wall hollow glass microspheres as novel potential nanocarriers for biomedical applications. Nanomed Nanotechnol Biol Med 6: 127-136, 2010.

LU J, TOY PH: Organic polymer supports for synthesis and for reagent and catalyst immobilization. Chem Rev 109: 815-838, 2009.

MEYER U, LARSSON A, HENTZE HP, CARUSO RA: Templating of porous polymeric beads to form porous silica and titania spheres. Adv Mater 14: 1768-1772, 2002.

SALINAS-CASTILLO A, CAMPRUBI-ROBLES M, MALLAVIA R: Synthesis of a new fluorescent conjugated polymer microsphere for chemical sensing in aqueous media. Chem Commun 46: 1263-1265, 2010.

SHEN S, SUN P, YANG L, SONG S, LI W, HU D: Colloidal liquid aphrons directed growth of solegel silica exhibiting bimodal porosities. Microporous Mesoporous Mater 214: 64-69, 2015.

SINITSYNA ES, WALTER JG, VLAKH EG, STAHL F, KASPER C, TENNIKOVA TB: Macroporous methacrylatebased monoliths as platforms for DNA microarrays. Talanta 93: 139-146, 2012.

STÖBER W, FINK A, BOHN E: Controlled growth of monodisperse silica spheres in the micron size range. $J$ Colloid Interface Sci 26: 62-62, 1968.

TSIOURVAS D, TSETSEKOU A, PAPAVASILIOU A, ARKAS M, BOUKOS N: A novel hybrid sol-gel method for the synthesis of highly porous silica employing hyperbranched poly(ethyleneimine) as a reactive template. Microporous Mesoporous Mater 175: 59-66, 2013.

UGELSTAD J, ELLINGSEN T, BERGE A, HELGEE B: Process for preparing magnetic polymer particles. US Patent 1988/4774265, 1988.

VELIKOVA N, VUEVA Y, IVANOVA Y, SALVADO I, FERNANDES M, VASSILEVA P, GEORGIEVA R, DETCHEVA A: Synthesis and characterization of sol-gel mesoporous organosilicas functionalized with amine groups. J Non-Cryst Solids 378: 89-95, 2013. 